13. Kuzmin O., Melnyk O., Zhuk L. Formation of diagnostics indicator $\mathrm{b}$ ase of the university scientific activity system // Technology audit and production reserves. 2018. Vol. 1, No. 4 (39). P. 9-15. doi:10.15587/2312-8372.2018.124396

14. Veyder M. Instrumenty berezhlivogo proizvodstva: Mini-rukovodstvo po vnedreniyu metodik berezhlivogo proizvodstva. Moscow: Alpina Pablisherz, 2011. 125 p.

15. Lean Lexicon a graphical glossary for Lean Thinkers / ed. by Marchwinski C., Shook J., Schroeder A. Lean Enterprise Institute, 2008. 136 p.
16. Dailey K. W. The Lean Manufacturing Pocket Handbook. Publishing Co., 2003. 42 p.

17. Oshchadlyve vyrobnytstvo: kontseptsiia, instrumenty, dosvid handbook / Omelianenko T. V. et al. Kyiv: KNEU, 2009. 157 p.

Kolos Iryna, PhD, Associate Professor, Certified Accounting Practitioner, Department of Accounting and Auditing, National University of Food Technologies, Kyiv, Ukraine, e-mail: irynakolos2016@gmail.com, ORCID: http://orcid.org/0000-0001-7134-1441

\section{Levchenko Ia., Kyrchata I., Shersheniuk $\mathbf{0}$.}

\title{
TESTING OF THE A5SESSMENT MODEL OF ENTERPRISE INVESTMENT ATTRACTIVENESS ON AN EXAMPLE OF UKRAINIAN MOTOR TRANSPORT ENTERPRISES
}

Об’єктом дослідження є модель оцінки інвестиційної привабливості підприємства (ІП). Більшість методів оцінки інвестиційної привабливості побудовані на визначенні та аналізі економічних показників за певними напрямками. Кожен з напрямків містить кілька показників, які суттєво впливають та всебічно відображають область діяльності підприємства. Мова ведеться як про якісні, так і кількісні показники. Одним з найбільш проблемних місць є об'єднання якісних та кількісних показників для визначення єдиного інтегрального показника ІП та перевірка такого підходу на підприємствах автомобільного транспорту. Використовуючи модель, можна вирішити найбільшу проблему, ие агрегувати інформачійні напрямки та індекси, визначити універсальний інтегральний показник інвестиційної привабливості підприємства.

Для вирішення, поставленої в роботі проблеми, були застосовані наступні методи наукових досліджень:

- критичний аналіз, абстрактно-логічний метод та узагальнення наукового досвіду - вдосконалення принципів оцінки IП;

- математичний та статистичний аналіз результатів дослідження, проведений за допомогою програмного забезпечення обробки статистичних даних, SPSS (v21.0) ma Microsoft Excel (2010).

Завдяки иим заходам було:

- перевірено адаптивність моделі оцінки ІП підприємства на прикладі автотранспортних підприємств (АTП);

- визначено ІП АТП та основні фактори впливу на ІП АТП;

- розраховано коефічієнти еластичності, відхилення фактичного показника ІП від оптимального;

- зроблено висновок про необхідність збільшення значень факторів, що впливають на IП АТП.

Враховуючи виявлені слабкі сторони (негативні наслідки) для кожного підприємства, можна створити перелік пріоритетних заходів, які будуть впроваджуватись у АТП, та запропонувати алгоритм прийняття управлінських рішень щодо оптимізащї рівня ІП АТП. На підставі отриманих даних можна розробити програму фінансової реструктуризацї, адаптовану до системи управління IП кожного вивченого АТП. Всі ці рекомендаиї дають можливість для подальших наукових розробок.

Ключові слова: інвестищійна привабливість, рівень інвестиційної привабливості, коефічієнти еластичності, автотранспортний сектор України.

\section{Introduction}

Aggravation of the struggle for investments is a result of a sharply increasing demand for additional resources, while the volume of investment capital lags behind the needs of the sector and economy as a whole.

The reduction in the volume of budget funding and limited own funds of enterprises determine a particular relevance of researches on providing motor transport enterprises (MTE) investment attractiveness (IA).
Increasing the investment attractiveness can help an enterprise to create competitive advantages, open opportunities for innovation, reduce operating risks and operating costs, and improve the enterprise's profitability.

This problem is urgent not only for MTEs of Kharkiv region, which, despite the existing development potential, favorable geographical location are unable to attract the necessary investment resources because of a rather low level of IA caused by a low level of profitability of MTEs and negative investment image of Ukraine. The importance 
of the problem grows under conditions of Ukraine's integration into the world economy, entering the international market, which leads to an increase in the number of potential competitors in obtaining investment resources.

\section{The object of research and its technological audit}

The object of research is the model for assessing of enterprise investment attractiveness on an example of Ukrainian motor transport enterprises.

The model for assessment of enterprise investment attractiveness is defined as the unit combining the internal, sectoral and regional factors. All three elements of enterprise IA should be used together.

The proposed model does not take into account the factors at the state level, as it is oriented to the internal assessment of the investment attractiveness of an enterprise.

The empirical study will carry out at enterprises of the motor transport sector, and the author realizes that results of a similar research in other sectors may differ, which will the basis for further discussions.

\section{The aim and objectives of research}

The aim of research is approbation of the model for assessing enterprise investment attractiveness and to test it on example of motor transport enterprises in Kharkiv region.

To achieve the aim of research, the following scientific objectives are identified:

1. To conduct an analysis of the current state of investment attractiveness of the enterprises of motor transport on example of the Kharkiv region of Ukraine.

2. To determine the investment attractiveness of each investigated enterprise and identify weaknesses (negative effects) for each enterprise.

\section{Research of existing solutions of the problem}

Evaluation of investment projects should be carried out with the help of quantitative assessment, which allows to comprehensively assess the advantages of the project for the company, and also represents the real level of valuation of the invested capital [1] on condition of intellectualization information for managing of any an enterprise [2].

Some scientists propose assessing IA by means of investment analysis. For this purpose, [3] introduces the concept of «investment productivity» and defines it as return on investment measured by the ratio of the GDP changes to investments. Author [4] speaks of «investment efficiency» and considers it the end result from realization of investments to be used. Thus, author [5] proposes to determine efficiency and feasibility of investing in traditional methods - DCF discounting, namely, net present value (NPV) and internal rate of return (IRR). The main drawback of this approach is the inability to assess managerial flexibility under uncertainty. Authors [6] argue that the definition of investment attractiveness should be carried out on the basis of factor analysis, since they are sure that each consumer, and, accordingly, the investor, has an individual taste and idea of attractiveness. This shows that each investor can have his own view on enterprise attractiveness. Authors [7] say that for each sector a model for determining enterprise IA should be developed on the basis of forecast estimates. They also define universal criteria that can be used to assess enterprise IA. Author [8,9] says that it is necessary to comprehensively assess enterprise investment attractiveness. To this end, he suggests using two models: the models imply assessing investment attractiveness based on quantitative indicators, the other model includes only qualitative indicators.

The models for assessment of investment enterprise attractiveness existing in the scientific literature are:

- «Model for quantifying the components of the innovation strategy» [9];

- «Model for business activity assessment» [10];

- «Assessment model on the basis of forecast estimates» [7];

- «Method for integral assessment of investment attractiveness of enterprises and organizations» of Agency on Prevention of Bankruptcy of Enterprises and Organizations (ABEO) [11], which was developed on the initiative of the administration of Agency on Prevention of Bankruptcy of Enterprises and Organizations $(\mathrm{ABEO})$ and registered in the Ministry of Justice of Ukraine.

It should be noted that the development of models for assessing investment attractiveness helps develop science. When the result is presented quantitatively, it becomes easy to understand. Results obtained by an integral assessment are especially simple for perception.

The carried out analysis has allowed singling out fundamental principles that are purposeful to apply in assessing investment attractiveness, the authors decided to describe criteria for assessment and analysis of investment attractiveness (Table 1).

Table 1

Directions of financial analysis of enterprise investment attractiveness

\begin{tabular}{|l|l|l|l|l|}
\hline \multicolumn{1}{|c|}{ Criteria for assessment } & $\begin{array}{c}\text { Author } \\
{[8,9]}\end{array}$ & $\begin{array}{c}\text { Author } \\
{[10]}\end{array}$ & $\begin{array}{c}\text { Authors } \\
{[7]}\end{array}$ & $\begin{array}{c}\text { ABE0 } \\
{[11]}\end{array}$ \\
\hline Property status & & & & \\
\hline Financial independence & & & & \\
\hline Financial stability & & & & \\
\hline Assets liquidity & & & & \\
\hline Profitability & & & & \\
\hline Business activity & & & & \\
\hline $\begin{array}{l}\text { Correcting the integral index with } \\
\text { regard to attractiveness of the region }\end{array}$ & & & & \\
\hline Sectoral criterion & & & & \\
\hline
\end{tabular}

The majority of the mentioned methods for assessment of investment attractiveness are built on determination and analysis of economic indicators by certain directions. Each of the mentioned directions contains a few indicators that substantially influence and comprehensively represent the area of an enterprise's activity. The biggest problem is combination of the indexes for determining a single integral index of investment attractiveness.

However, at the present stage the conceptual apparatus and objectives of management of MTE IA are not completely formed, a clear system of factors influencing 
the MTE IA level, indicators and methods for evaluating the MTE IA level is not developed, the issue of information support of the system for managing MTE IA is studied insufficiently. That is why there growing a need for development and implementation of the system for managing MTE IA, which will allow to quickly identify the factors influencing the MTE IA level and to qualitatively affect these factors in order to optimize MTE functioning. This will enable attracting additional investment resources and direct them to the enterprise development.

\section{Methods of research}

To solve the problem raised in the article, the following scientific research methods are applied: critical analysis, abstract-logical method and generalization of scientific experience - at improving the principles for assessing investment attractiveness, mathematical and statistical analysis.

\section{Research results}

On the basis of the assessment model, which combines quantitative and qualitative indicators of IA, which was presented and proved in the works [12, 13], let's assess the MTE IA on example of the Kharkiv region.

On the bases of statistic information which presented in [14] in the course of the calculations there were obtained synthetic indicators by the enterprise groups, on the basis of which it is possible to carry out the study and determine, which of the synthetic indicators has the least value. On this basis it will be possible to identify perspective directions of further development of the enterprise and work out recommendations on increasing the MTE IA. The results are presented in Table 2.

On the basis of Table 2 the following conclusion can be made: as of 2016 the most negative indicators are:

- the enterprise Truck Fleet No. 2 are the indicators of Group;

- PJSC MTE - 16363 - the indicators of Group 5;

- PJSC Krasnograd MTE - 16345 - the indicators

of Group 4 and 6;

- PJSC MTE - 16350 - the indicators of Group 4,

5 and 6 ;

- PJSC MTE - 16329 - the indicators of Group 1, 4 and 5 ;

- OJSC MTE - 16351 -the indicators of Group 1, 4 and 6 ;
- Private JSC MTE - the indicators of Group 5 and 6; - Private JSC Kharkiv MTE 16368 - the indicators of Group 1, 4 and 5 .

Thus, it can be concluded that the most negative indicators, i. e., the indicators that considerably lower the MTE IA level for our sample of enterprises as of 2016 are the indicators of Group 4 and 5. They are coefficient of absolute liquidity, working capital, coefficient of profitability of own capital, operating income margin.

The negative factors of influence for each of the studied enterprise have been determined. Thus, to increase the MTE IA level, it is necessary to improve the following indicators:

- Truck Fleet No. 2 - indicators of assets liquidity, indicators of profitability;

- PJSC MTE - 16363 - indicators of profitability;

- PJSC Krasnograd MTE - 16345 - indicators of assets liquidity, indicators of profitability, indicators of business activity;

- PJSC MTE - 16350 - indicators of assets liquidity, indicators of profitability, indicators of business activity;

- PJSC MTE - 16329 - indicators of assets liquidity, indicators of profitability;

- OJSC MTE - 16351 - indicators of assets liquidity, indicators of business activity;

- Private JSC MTE - indicators of property status, indicators of profitability, indicators of business activity; - Private JSC Kharkiv MTE 16368 - indicators of property status, indicators of assets liquidity, indicators of profitability.

As the main factors of influencing on the MTE IA level was defined, so we can calculate the elasticity coefficients. They allow describe relative changes in the studied economic indicator (IA level) under the influence of a single economic factor (property status, financial independence, financial stability, assets liquidity, business activity, profitability). This level determines the indicator under conditions of permanency of other influence factors. The elasticity coefficient is presented by the following formula in the work [15].

On the basis of the equation which presented in the work [15] calculated elasticity coefficients of the IA level of the studied enterprises are calculated under the influence of indicators of property status, financial independence, financial stability, assets liquidity, business activity, profitability (Table 3).

The synthetic indicators by the groups (components) of motor transport enterprises investment attractiveness as of 2016

\begin{tabular}{|c|c|c|c|c|c|c|}
\hline \multirow{2}{*}{ Name of the MTE } & \multicolumn{6}{|c|}{2016} \\
\hline & Group 1 & Group 2 & Group 3 & Group 4 & Group 5 & Group 6 \\
\hline Truck Fleet No. 2 & 0.769 & 0.840 & 0.514 & -0.134 & -0.181 & 0.005 \\
\hline PJSC MTE - 16363 & 0.954 & 0.355 & 0.030 & 0.902 & -0.199 & 0.652 \\
\hline PJSC Krasnograd MTE - 16345 & 0.229 & 0.285 & 0.225 & -0.794 & 0.491 & -0.459 \\
\hline PJSC MTE - 16350 & 0.664 & 0.296 & 0.488 & -0.707 & -0.257 & -0.356 \\
\hline PJSC MTE - 16329 & 0.267 & 0.328 & 0.925 & -0.448 & -0.324 & 0.987 \\
\hline OJSC MTE - 16351 & 0.238 & 0.297 & 0.520 & -0.676 & 0.912 & -0.430 \\
\hline Private J5C MTE & 0.083 & 0.293 & 0.337 & 0.364 & -0.438 & -0.380 \\
\hline Private JSC Kharkiv MTE 16368 & 0.076 & 0.289 & 0.111 & -0.014 & -0.385 & 0.553 \\
\hline
\end{tabular}


The coefficients of elasticity of the level of motor transport enterprises investment attractiveness in Kharkiv region

\begin{tabular}{|c|c|c|c|c|c|c|}
\hline Name of the MTE & $\begin{array}{l}\text { Influence } \\
\text { of Group } 1\end{array}$ & $\begin{array}{l}\text { Influence } \\
\text { of Group } 2\end{array}$ & $\begin{array}{l}\text { Influence } \\
\text { of Group } 3\end{array}$ & $\begin{array}{l}\text { Influence } \\
\text { of Group } 4\end{array}$ & $\begin{array}{l}\text { Influence } \\
\text { of Group } 5\end{array}$ & $\begin{array}{l}\text { Influence } \\
\text { of Group } 6\end{array}$ \\
\hline Truck Fleet No. 2 & 0.406 & 0.384 & 0.450 & 0.272 & 0.286 & 0.174 \\
\hline PJSС MTE - 16363 & 0.609 & 0.531 & 0.243 & 0.640 & 0.386 & 0.778 \\
\hline PJSC Krasnograd MTE - 16345 & 0.343 & 0.403 & 0.341 & 0.584 & 0.404 & 0.424 \\
\hline PJSС MTE - 16350 & 0.20 & 0.13 & 0.19 & 0.21 & 0.23 & 0.24 \\
\hline PJ5С MTE - 16329 & 0.217 & 0.262 & 0.295 & 0.214 & 0.202 & 0.284 \\
\hline OJSC MTE - 16351 & 0.091 & 0.111 & 0.145 & 0.117 & 0.130 & 0.120 \\
\hline Private J5C MTE & 0.026 & 0.067 & 0.068 & 0.068 & 0.059 & 0.061 \\
\hline Private J5C Kharkiv MTE 16368 & 0.083 & 0.219 & 0.126 & 0.033 & 0.151 & 0.175 \\
\hline
\end{tabular}

On the basis of the obtained data (Table 3 ) it becomes possible to trace the following regularity:

- to increase the IA level of Truck Fleet No. 2 by $1 \%$, it is necessary to increase the indicators of property status, financial independence, financial stability, assets liquidity, profitability or business activity by $0.406 \%$, $0.384 \%, 0.450 \%, 0.272 \%, 0.286 \%$ and $0.174 \%$ respectively;

- to increase the IA level of PJSC MTE - 16363 by $1 \%$, it is necessary to increase the indicators of property status, financial independence, financial stability, assets liquidity, profitability or business activity by $0.609 \%, 0.531 \%, 0.243 \%, 0.640 \%, 0.386 \%$ and $0,778 \%$ respectively;

- to increase the IA level of PJSC Krasnograd MTE 16345 by $1 \%$, it is necessary to increase the indicators of property status, financial independence, financial stability, assets liquidity, profitability or business activity by $0.343 \%, 0.403 \%, 0.424 \%, 0.584 \%, 0.404 \%$ and $0.341 \%$ respectively;

- to increase the IA level of PJSC MTE - 16350 by $1 \%$, it is necessary to increase the indicators of property status, financial independence, financial stability, assets liquidity, profitability or business activity by $0.20 \%$, $0.13 \%, 0.19 \%, 0.21 \%, 0.23 \%$ and $0.24 \%$ respectively; - to increase the IA level of PJSC MTE - 16329 by $1 \%$, it is necessary to increase the indicators of property status, financial independence, financial stability, assets liquidity, profitability or business activity by $0.217 \%, 0.262 \%, 0.295 \%, 0.214 \%, 0.202 \%$ and $0.284 \%$ respectively;

- to increase the IA level of OJSC MTE - 16351 by $1 \%$, it is necessary to increase the indicators of property status, financial independence, financial stability, assets liquidity, profitability or business activity by $0.091 \%, 0.111 \%, 0.145 \%, 0.117 \%, 0.130 \%$ and $0.120 \%$ respectively;

- to increase the IA level of Private JSC MTE by $1 \%$, it is necessary to increase the indicators of property status, financial independence, financial stability, assets liquidity, profitability or business activity by $0.026 \%, 0.067 \%, 0.068 \%, 0.068 \%, 0.059 \%$ and $0.061 \%$ respectively;

- to increase the IA level of Private JSC Kharkiv MTE 16368 by $1 \%$, it is necessary to increase the indicators of property status, financial independence, financial stability, assets liquidity, profitability or business activity by $0.083 \%, 0.219 \%, 0.126 \%, 0.033 \%$, $0.151 \%$ and $0.175 \%$ respectively.

On the basis of the obtained data concerning the MTE IA level let's calculate the deviation of the actual index from the optimal one. As an optimal one there taken the indicator value of 0.5 - for enterprises with a low IA level and 1 - for enterprises with a high IA level (Table 4).

Having calculated the deviation of the actual IA level from the optimal one (Table 4), it is possible to make a conclusion regarding the need for increasing the values of the factors influencing the MTE IA level (Table 5).

The deviation of the actual index from the optimal one as of 2016

\begin{tabular}{|l|c|c|c|}
\hline \multicolumn{1}{|c|}{ Name of the MTE } & The optimal level (index) of IA & The actual level (index) of IA & Deviation of the actual index from the optimal one \\
\hline Truck Fleet No. 2 & 1 & 0.423 & -0.57681 \\
\hline PJSC MTE - 16363 & 1 & 0.456 & -0.54373 \\
\hline PJSC Krasnograd MTE - 16345 & 0.5 & 0.017 & -0.48303 \\
\hline PJSC MTE - 16350 & 0.5 & 0.027 & -0.47336 \\
\hline PJSC MTE - 16329 & 1 & 0.487 & -0.51317 \\
\hline OJSC MTE - 16351 & 0.5 & 0.201 & -0.29947 \\
\hline Private J5C MTE & 0.5 & 0.039 & -0.46114 \\
\hline Private JSC Kharkiv MTE 16368 & 0.5 & 0.103 & -0.39655 \\
\hline
\end{tabular}


The dynamics of the required changes in the values of factors influencing the level of motor transport enterprises investment attractivenes

\begin{tabular}{|c|c|c|c|c|c|c|c|}
\hline \multirow{2}{*}{ Name of the MTE } & \multirow{2}{*}{$\begin{array}{l}\text { The ratio of the actual and } \\
\text { optimal level of MTE IA }\end{array}$} & \multicolumn{6}{|c|}{ The degree of the indicator increase by the groups } \\
\hline & & 1 & 2 & 3 & 4 & 5 & 6 \\
\hline Truck Fleet No. 2 & 57.681 & 23.42 & 22.15 & 25.96 & 15.69 & 16.50 & 10.04 \\
\hline PJSС MTE - 16363 & 54.373 & 33.11 & 28.87 & 13.21 & 34.80 & 20.99 & 42.30 \\
\hline PJSC Krasnograd MTE - 16345 & 96.606 & 33.14 & 38.93 & 32.94 & 56.42 & 39.03 & 40.96 \\
\hline PJSС MTE - 16350 & 94.672 & 18.93 & 12.31 & 17.99 & 19.88 & 21.77 & 22.72 \\
\hline PJSС MTE - 16329 & 51.317 & 11.14 & 13.45 & 15.14 & 10.98 & 10.37 & 14.57 \\
\hline OJSC MTE - 16351 & 59.894 & 5.45 & 6.65 & 8.68 & 7.01 & 7.79 & 7.19 \\
\hline Private J5C MTE & 92.228 & 2.40 & 6.18 & 6.27 & 6.27 & 5.44 & 5.63 \\
\hline Private J5C Kharkiv MTE 16368 & 79.31 & 6.58 & 17.37 & 9.99 & 2.62 & 11.98 & 13.88 \\
\hline
\end{tabular}

On the basis of the data from Table 5 it can be assumed that to achieve the optimal level of MTE IA the enterprises:

- Truck Fleet No. 2 needs to increase the indicators of property status, financial independence, financial stability, assets liquidity, profitability or business activity by $23.42 \%, 22.15 \%, 25.96 \%, 15.69 \%, 16.50 \%$ and $10.04 \%$ respectively;

- PJSC MTE - 16363 needs to increase the indicators of property status, financial independence, financial stability, assets liquidity, profitability or business activity by $33.11 \%, 28.87 \%, 13.21 \%, 34.80 \%, 20.99 \%$ and $42.30 \%$ respectively;

- PJSC Krasnograd MTE needs to increase the indicators of property status, financial independence, financial stability, assets liquidity, profitability or business activity by $33.14 \%, 38.93 \%, 32.94 \%, 56.42 \%, 39.03 \%$ and $40.96 \%$ respectively;

- PJSC MTE - 16350 needs to increase the indicators of property status, financial independence, financial stability, assets liquidity, profitability or business activity by $18.93 \%, 12.31 \%, 17.99 \%, 19.88 \%, 21.77 \%$ and $22.72 \%$ respectively;

- PJSC MTE - 16329 needs to increase the indicators of property status, financial independence, financial stability, assets liquidity, profitability or business activity by $11.14 \%, 13.45 \%, 15.14 \%, 10.98 \%, 10.37 \%$ and $14.57 \%$ respectively;

- OJSC MTE - 16351 needs to increase the indicators of property status, financial independence, financial stability, assets liquidity, profitability or business activity by $5.45 \%, 6.65 \%, 8.68 \%, 7.01 \%, 7.79 \%$ and $7.19 \%$ respectively;

- Private JSC MTE needs to increase the indicators of property status, financial independence, financial stability, assets liquidity, profitability or business activity by $2.40 \%, 5.63 \%, 6.27 \%, 6.27 \%, 5.44 \%$ and $6.18 \%$ respectively;

- Private JSC Kharkiv MTE 16368 needs to increase the indicators of property status, financial independence, financial stability, assets liquidity, profitability or business activity by $6.58 \%, 17.37 \%, 9.99 \%, 2.62 \%$, $11.98 \%$ and $13.88 \%$ respectively.

\section{SWOT analysis of research results}

Strengths. The strengths of the application of the model for assessing the investment attractiveness of an enterprise are:

- unification of qualitative and quantitative, as well as external and internal factors of the enterprise;

- the possibility of obtaining one integral indicator, which determines the level of investment attractiveness of the enterprise.

Weaknesses. This model is approved only at the enterprises of the motor transport industry, therefore

- when applying this model to the enterprises of other industries, the set of factors may differ from the proposed one;

- this model does not take into account factors at the state level.

Opportunities. The research was conducted in one region of Ukraine - Kharkiv region. But regions with similar characteristics exist in countries with emerging economies, indicators forming a model for assessing the investment attractiveness of an enterprise may be different and specific for such regions, but they can be adapted, and the model can be implemented in other regions. There are a lot of such regions and the task of science is support of all of them in their development and European integration.

Threats. This model does not take into account such an important factor as the labor potential of the enterprise. When implementing this factor in the structure of the model, the values may differ significantly.

\section{Conclusions}

1. In the article it is established and argued that, for assessment of enterprise investment attractiveness, a system approach to the integrity, functionality and applicability of assessment methods is essential. The model for assessment of enterprise investment attractiveness is seen as a system of processes, consisting of factors of enterprise investment attractiveness with the determination of weighting coefficients for each of one.

An analysis of the current state of investment attractiveness of the enterprises of motor transport on example 
of the Kharkiv region of Ukraine was conducted. The investment attractiveness of each investigated enterprise was determined.

2. Taking into account the identified weaknesses (negative effects) for each enterprise, it is possible to form a list of priority measures to be implemented at MTE, and it is possible to propose an algorithm for making the sound management decisions on optimizing the MTE IA level. On the basis of the obtained data it is possible to develop the program of financial restructuring adapted to the system for managing IA of each studied MTE. All those recommendations give a possibility for further scientific elaborations.

\section{References}

1. Drabek J., Merkova M. The Importance of Investment Audit for the Company // Procedia Economics and Finance. 2015. Vol. 34. P. 187-193. doi:10.1016/s2212-5671(15)01618-4

2. Formation of the concept of intellectualization information provision for managing an enterprise / Grinko A. et al. // Eastern-European Journal of Enterprise Technologies. 2017. Vol. 5, No. 3 (89). P. 4-14. doi:10.15587/1729-4061.2017.111859

3. Mirkin Ya. M. Chastno-gosudarstvennoe partnerstvo v vysshem obrazovanii i nauchnoi sfere: mehanizmy upravleniya imushhestvom, privlecheniya finansirovaniya, upravleniya soderzhaniem obrazovaniya i nauchnoi deyatel'nosti. Moscow, 2009. 105 p. URL: http://www.mirkin.ru/_docs/_budgetfin/_obrprog/3_1. pdf

4. Tsarev V. V., Kantarovich A. A. Otsenka stoimosti biznesa. Teoriya i metodologiya. Moscow: YUNITI-DANA, 2012. 572 p.

5. Anamari-Beatrice S. Real Options a Solution for Evaluating Public Private Partnerships // Procedia Economics and Finance. 2014. Vol. 15. P. 583-586. doi:10.1016/s2212-5671(14)00516-4

6. Mittal A., Jhamb D. Determinants of Shopping Mall Attractiveness: The Indian Context // Procedia Economics and Finance. 2016. Vol. 37. P. 386-390. doi:10.1016/s2212-5671(16)30141-1

7. Rebiasz B., Maciol A. Hybrid Data in the Multiobjective Evaluation of Investments // Procedia Computer Science. 2014. Vol. 35 P. 624-633. doi:10.1016/j.procs.2014.08.144
8. Rolik Y. A. Complex estimation of industrial enterprise's innovation strategy: proceeding // MK-2012-6. Innovation in the industrial sector. Kazan, 2012. Vol. 1. P. 247-251.

9. Rolik Y. A. A Complex Approach to Evaluating the Innovation Strategy of a Company to Determine its Investment Attractiveness // Procedia - Social and Behavioral Sciences. 2013. Vol. 99. P. 562-571. doi:10.1016/j.sbspro.2013.10.526

10. Nizielska A. The criteria, instruments, and determinants of investment attractiveness of Silesia: experts opinions // Journal of economics \& management. 2012. Vol. 8. P. 53-70.

11. Pro zatverdzhennya Metodyky intehral'noyi otsinky investytsiynoyi pryvablyvosti pidpryyemstv ta orhanizatsiy: Order of the Agency for the Prevention of Bankruptcy of Enterprises and Organizations No. 22 from February 23, 1998. URL: http:// zakon3.rada.gov.ua/laws/show/z0214-98

12. Dmytriyev I., Levchenko I. Otsiniuvannia investytsiynoi pryvablyvosti pidpryiemstva ta upravlinnia yii pokaznykamy // Aktualni problemy ekonomiky. 2017. No. 5 (191). P. 89-99.

13. Levchenko I. Optymizatsiya rivnia investytsiynoi pryvablyvosti avtotransportnykh pidpryiemstv // Zbirnyk naukovykh prats Cherkaskoho derzhavnoho tekhnolohichnoho universytetu. Seriya: Ekonomichni nauky. 2015. Vol. 39, No. 2. P. 150-155.

14. Ahentstvo z rozvytku infrastruktury fondovoho rynku Ukrainy. Statystychna informatsiya. URL: http://smida.gov.ua/db/participant/01268414

15. Fathutdinov R. A. Strategicheskiy marketing. Saint Petersburg: Piter, 2013. 347 p.

Levchenko Iaroslava, Assistant, Department of Economics and Entrepreneurship, Kharkiv National Automobile and Highway University, Ukraine, e-mail: slavalevcenko1984@gmail.com, ORCID: http://orcid.org/0000-0002-4979-1101

Kyrchata Iryna, PhD, Associate Professor, Department of Economics and Entrepreneurship, Kharkiv National Automobile and Highway University, Ukraine, e-mail: kirchatayairina@gmail.com, ORCID: http://orcid.org/0000-0002-0270-1586

Shersheniuk Olena, PhD, Associate Professor, Department of Economics and Entrepreneurship, Kharkiv National Automobile and Highway University, Ukraine, e-mail: kirchatayairina@gmail.com, ORCID: http://orcid.org/ 0000-0002-9959-2725 